\title{
NEPHROPROTECTIVE OF ANTHOCYANIN PIGMENTS EXTRACT FROM RED \\ CABBAGE (BRASSICA OLERACEA L. VAR. CAPITATA F. RUBRA) AGAINST GENTAMICIN-CAPTOPRIL-INDUCED NEPHROTOXICITY IN RATS
}

\author{
SHAUM SHIYAN*, HERLINA, LITA RIZKIKA SARI \\ Program Studi Farmasi, Fakultas Matematika dan Ilmu Pengetahuan Alam, Universitas Sriwijaya, Jalan Palembang-Prabumulih Km 32, \\ Indralaya, Sumatera Selatan, Indonesia. Email: shaumshiyan@unsri.ac.id
}

Received: 22 January 2018, Revised and Accepted: 10 March 2018

\begin{abstract}
Objective: Red cabbage (Brassica oleracea L. var. Capitata f. rubra) has a fairly high anthocyanin content and is a source of powerful antioxidants. This study is basic for the development of a nutraceutical, which has nephroprotective activity.

Methods: Red cabbage was extracted using ethanol and water with a mixture of citric acid with a variation of 1, 2, and 3\%. The total anthocyanin was determined with $\mathrm{pH}$-differential method. The Wistar strain male rats were divided into five groups. Group 1 as a negative control, Group 2 as a positive control treated with Vitamin E dose of $400 \mathrm{mg} / \mathrm{kg}$ BW day. Groups 3-5 were treated with three different extract dose of 100, 200, and 400 mg/kg BW. Gentamicin was given intraperitoneally and captopril orally for 3 days. Extracts and Vitamin E were administrated orally for 15 days after induction of gentamicin-captopril. Nephroprotective activity was determined by measuring the levels of serum creatinine, blood ureum, and macroscopic kidney.
\end{abstract}

Results: The combination of $96 \%$ ethanol and citric acid 3\% showed the percent of free radical 2,2-diphenyl-1-picrylhydrazyl arrest of 75.23\% and contained $53.49 \pm 5.01 \mathrm{mg} / \mathrm{L}$ of total anthocyanin. The anthocyanin pigment from red cabbage extract can decrease the levels of creatinine and ureum, which dose of $100 \mathrm{mg} / \mathrm{kg} \mathrm{BW}$ showed the highest value of $48.72 \%$. There were differences in the macroscopic morphology in the rat kidney.

Conclusion: Based on the results, we concluded that ethanol with 3\% citric acid produced higher anthocyanin and showed nephroprotective activity.

Keywords: Anthocyanin, Brassica oleracea L., Captopril, Gentamicin, Nephroprotective, Creatinine.

(C) 2018 The Authors. Published by Innovare Academic Sciences Pvt Ltd. This is an open access article under the CC BY license (http://creativecommons. org/licenses/by/4. 0/) DOI: http://dx.doi.org/10.22159/ajpcr.2018.v11i4.20373

\section{INTRODUCTION}

Red cabbage is one of the many vegetables that contain anthocyanins. It is a source of anthocyanin with potent antioxidant activity. The previous research showed that an extract of red cabbage anthocyanin pigments has IC $_{50}$ values with hydrogen peroxide capture methods $19.90 \mathrm{mg} / \mathrm{mL}$, nitric oxide $47.55 \mathrm{mg} / \mathrm{mL}$, and 2,2-diphenyl-1-picrylhydrazyl (DPPH) radical $6.02 \mathrm{mg} / \mathrm{mL}$ [1-3]. The potential of these antioxidants can be used in the treatment of oxidative stress in the body.

The antioxidant activity of the anthocyanin potentially inhibits the renal damage. An acute renal disorder can cause kidney malfunction. It is characterized by the higher serum creatinine levels on blood [4,5]. Anthocyanin improved the situation glomerulosclerosis characterized by kidney filtration dysfunction in diabetes treatment and reported it as antagonized glomerular angiogenesis due to chronic hyperglycemia and diabetes [6-9]. Pigment anthocyanin extracts can prevent oxidative stress and microvascular complications and rise kidney tissue damage in diabetics $[10,11]$.

Various studies confirmed that red cabbage anthocyanins can be used as a nutraceutical ingredient, especially as a nephroprotective agent. Therefore, a study on the effects of the extract of anthocyanin pigments of red cabbage to improved kidney function was performed. Anthocyanin extract as the test sample is selected, based on the simple optimization of the extraction procedure. Nephrotoxicity in rats was performed by inducing gentamicin and captopril, followed the establish procedure [12-15]. Nephroprotective activity is determined by measuring levels of creatinine, ureum, and macroscopic kidney. Hopefully, this study can provide information about the nephroprotective activity of red cabbage anthocyanin extract in rats.
Moreover, it can be used as a basic to develop nutraceutical with a nephroprotective activity.

\section{METHODS}

Plant material

Flos red cabbage was collected from Ciwidey, Bandung, Indonesia, during February to April 2016. The red cabbage was then transferred in laboratory and stored at $2-8^{\circ} \mathrm{C}$ until extraction procedures.

Animals and ethical approval

Male rats (150-200 g) obtained from the pharmacology unit of our institution were housed under standard conditions with free access to commercial chow and water. All procedures described here were performed with approval from the Health Research Review Committee of Mohammad Hoesin Central Hospital and Faculty of Medicine, Universitas Sriwijaya, Palembang, Indonesia (Ethical approval certificate No. 114/kepkrsmhfkunsri/2016).

\section{Optimization of anthocyanin extraction}

A simple optimization of extraction was performed by comparing the solvents. The solvents used were ethanol $90 \%$ and water with citric acid variation of 1,2 , and $3 \%$. The extraction process was done with the same procedure. Each extract was obtained by testing the arrest of radical DPPH, yield calculation, and determination of total anthocyanin.

\section{Extraction procedures}

Red cabbage as much as $10 \mathrm{~g}$ was added to $30 \mathrm{~mL}$ of solvent (ethanol/ water) with a variation of citric acid $(1,2$, and $3 \%)$ and then ground. Mass, in the form of a slurry, was put in a dark tube and $30 \mathrm{ml}$ of solvent was added to it. Measurement of $\mathrm{pH}$ in each tube was performed. 
Extraction was done by maceration at room temperature for $24 \mathrm{~h}$. The supernatant was centrifuged for $10 \mathrm{~min}$ at a speed of $4000 \mathrm{rpm}$. It was taken and concentrated to obtain a concentrated extract [16-18].

\section{Anthocyanin identification}

The test method of anthocyanin identification was done using $\mathrm{HCl}$ and $\mathrm{NaOH} 2 \mathrm{M}$. A stable deep red color formation was resulted when tested with $\mathrm{HCl}$, while with $2 \mathrm{M} \mathrm{NaOH}$ the red color turned green blue and faded slowly, indicating positive anthocyanin.

\section{DPPH free radical scavenging assay}

To quantitatively estimate free radical scavenging activity, $1 \mathrm{~mL}$ of $0.3 \mathrm{mM}$ DPPH was added to $2.5 \mathrm{~mL}$ anthocyanin pigment extract, and the mixture was homogenized and incubated for 30 min. A blank was also prepared without using the extract. By spectroscopic method, the percentage of reduction of DPPH absorbance at maximum $\lambda$ was calculated to determine the antioxidant activity [19-21].

\section{Total anthocyanin content}

The percentage of anthocyanin content was determined using the $\mathrm{pH}$ differential method [16,22-24]. Two samples were prepared, the first diluted with $0.025 \mathrm{M} \mathrm{KCl}, \mathrm{pH} 1$, and incubated for $15 \mathrm{~min}$, and the second diluted with $0.4 \mathrm{M} \mathrm{Na}$ acetate, $\mathrm{pH} 4.5$, and incubated for $5 \mathrm{~min}$. Each solution's absorbance at $700 \mathrm{~nm}$ and maximum wavelength was measured.

\section{Gentamicin-captopril-induced nephrotoxicity in rats}

Rats were acclimatized for 1 week. To induce kidney failure in rats, $100 \mathrm{mg} / \mathrm{kg}$ BW gentamicin (intraperitoneally) and $10 \mathrm{mg} / \mathrm{kg} \mathrm{BW}$ captopril (orally) were administered for 3 days [25,26]. Kidney failure was confirmed based on the levels of creatinine and ureum in urine $[14,15,23,26]$

\section{Nephroprotective activity}

The rats were grouped into five treatment groups, consisting of five rats in each group. In the negative control group, the rats were given distilled water. In the positive control group, the rats were given Vitamin E $400 \mathrm{mg} / \mathrm{kg}$ BW once a day orally. In the Group 1, 2, and 3 as the treatment group of the extract, the rats were given extract anthocyanin pigments with doses of 100,200 , and $400 \mathrm{mg} / \mathrm{kg} \mathrm{BW}$ orally daily, respectively. Provision of test compounds was initiated when the rat already had kidney failure or has elevated levels of creatinine and ureum. Measurement of biochemical parameters was performed on days 0,4 , and 20 . The measurement of creatinine level was performed used reagents human gesellschaft liquicolor creatinine kit, while the ureum level was measured using the ureum reagent urea urease kit (Dialab). Absorption was measured using a photometer.

\section{Macroscopic parameter of kidneys}

Phenobarbital injected rats were terminated after 10 min using the neck dislocation method and then dissected to extract the kidneys. Both of the kidneys were then weighed and their shape and color were observed.

\section{Statistical analysis}

The data obtained were presented in tables, charts, and images. Biochemical parameters (creatinine and ureum) were statistically analyzed, including the normality test and the one-way ANOVA test. There was a statistically significant difference if $p<0.05$. The significant differences between the groups were determined with LSD post hoc test and paired samples t-test.

\section{RESULTS}

\section{Optimization of extracts pigments anthocyanin}

Optimization was performed to obtain the extract with higher antioxidant activity and total anthocyanin content. Antioxidant activity assay of extracts from various acids was performed at $\lambda$ max $515 \mathrm{~nm}$. The result showed in Table 1, a mixture of ethanol 96\% and citric acid 3\% showed the highest percent inhibition at $75.23 \pm$
$0.49 \%$. The more the anthocyanin content, the higher the antioxidant activity.

Citric acid 3\% was more effective for extracting anthocyanin pigments from red cabbage and showed a higher DPPH radical capture than the other citric acid concentration. The $\mathrm{pH}$ of the pigment decreased with the increasing of concentration of the citric acid that was added. Based on a previous research, we observed that citric acid $3 \%$ was the best acid in red cabbage anthocyanin extraction.

\section{Total anthocyanin}

The total anthocyanin content was measured using a $\mathrm{pH}$ differential method. The total sample dissolved in the two kinds of solutions which have different $\mathrm{pH}$ values, respectively. The difference of the two measurements will show the amount of anthocyanin [16,22]. This analysis was done using the ultraviolet-visible spectrophotometer at two wavelengths, 528 and $700 \mathrm{~nm}$. A wavelength of $528 \mathrm{~nm}$ was the result of the measurement of the absorption spectrum $\lambda$ max extract anthocyanin expected sianidin a type of anthocyanin. Absorption at $700 \mathrm{~nm}$ was used as a correction factor. The highest concentration of anthocyanin content presence in ethanol solvent with 3\% acid citric was $53.49 \pm 5.01 \mathrm{mg} / \mathrm{L}$.

\section{Gentamicin-captopril-induced nephrotoxicity in rats}

The creatinine and blood ureum levels before induction day 0 and after induction day 4 is shown in Fig. 1. It was performed to monitor the process of induction (nephrotoxicity). All groups of test animals had increased levels of creatinine and ureum. The increase of creatinine and ureum processed statistically to see the significance.

The normality test of increased creatinine level showed the significance $>0.05$ of all treatments, of which the data distribution was normal. The significance on the one-way ANOVA was $0.268>0.05$. This showed that there was no significant difference on increased creatinine levels in all groups. Furthermore, the data were tested with paired t-test and the significance was $0.000<0.05$. The means that there was a difference of average creatinine levels before and after induction. Based on these results, the animals had an increase of creatinine levels significantly and uniformly in all treatment groups after induction at day 4. Ureum levels also increased significantly and uniformly in all treatment groups.

\section{NEPHROPROTECTIVE ACTIVITY}

The creatinine and blood ureum levels of rats before (day 4) and after treatment (day 20) showed that the levels of all groups were decreased (Fig. 1). The decreased creatinine and ureum levels in the negative control group were due to the natural recovery mechanisms undertaken by the body. Repairment of kidney function was naturally due to animal's homeostasis $[12,13,27,28]$. The decrease of creatinine and ureum levels showed the effectiveness of the compound as a drug. The larger decreased value produced the better activity in the repairment of kidney function. The creatinine and ureum levels before and after treatment was showed in Fig. 1 and Table 2.

The smallest decrease of creatinine and ureum levels was shown by the negative control group. The largest value decrease in creatinine and ureum is shown in Group 3, followed by Groups 4 and 5. The group of dose $100 \mathrm{mg} / \mathrm{kg} \mathrm{BW}$ was more effective than the control and the other treatment groups in reduced creatinine and ureum levels. This suggested that anthocyanin of red cabbage extract dose of $100 \mathrm{mg} / \mathrm{kg}$ BW could potentially accelerate the repairment of kidney function.

\section{Macroscopic parameter of kidneys}

The macroscopic observation of the kidney organ focused on weight, color, and shape of the surface. The result showed that the changes in renal anatomy can vary even in the same treatment group. The macroscopic picture of the kidney (Fig. 2) showed that in the negative control, the color changed from red-brown to dark brown and the organ surface of the kidney is not smooth (not normal), indicating an abnormal kidney. 


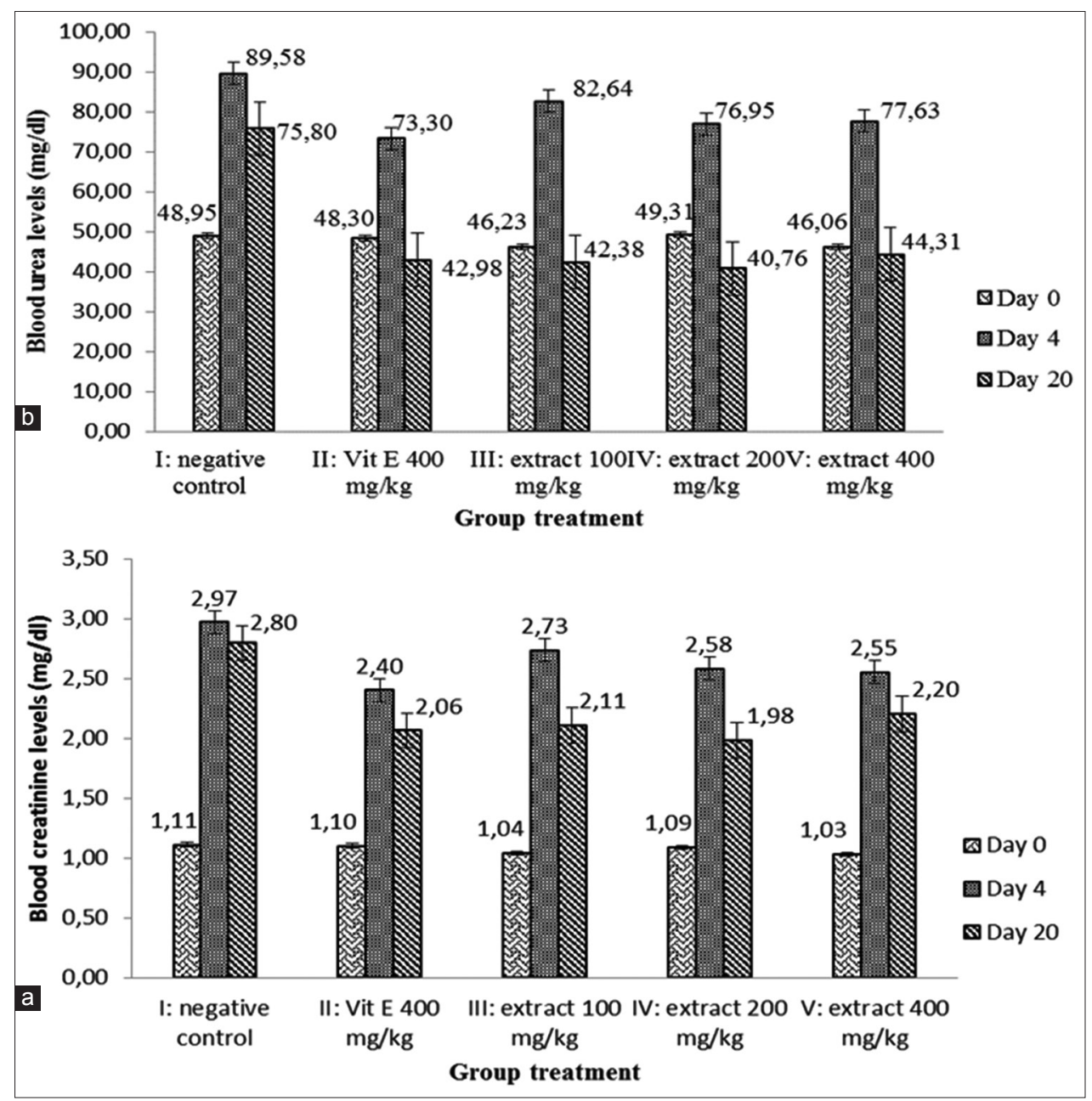

Fig. 1: Profile blood creatinine and ureum level various groups treatment, day 0: Before induced gentamicin-captopril; day 4: After induced gentamicin and day 20 after treatment

Table 1: Optimization of extract pigment anthocyanin from various solvents and various acids

\begin{tabular}{llll}
\hline Solvent and acid & Yield extract (\%) ${ }^{\mathbf{a}}$ & \% Inhibition $\mathbf{D P P H}^{\mathbf{a}}$ & Total anthocyanin (mg/l) $^{{ }^{a}}$ \\
\hline Ethanol+citric acid 1\% & $18.90 \pm 0.46$ & $72.87 \pm 0.85$ & $33.79 \pm 2.86$ \\
Ethanol+citric acid 2\% & $24.19 \pm 1.22$ & $73.30 \pm 0.82$ & $46.03 \pm 4.62$ \\
Ethanol+citric acid 3\% & $21.87 \pm 1.08$ & $75.23 \pm 0.49$ & $53.49 \pm 5.01$ \\
Water+citric acid 1\% & $23.24 \pm 1.05$ & $43.87 \pm 3.85$ & $21.54 \pm 2.89$ \\
Water+citric acid 2\% & $24.73 \pm 0.74$ & $41.89 \pm 5.17$ & $21.87 \pm 3.94$ \\
Water+citric acid 3\% & $19.70 \pm 1.07$ & $59.28 \pm 4.85$ & $33.40 \pm 2.69$ \\
\hline
\end{tabular}

Table 2: Average value of creatinine and ureum level decrease

\begin{tabular}{|c|c|c|c|c|c|c|}
\hline \multirow[t]{3}{*}{ Sample } & \multicolumn{3}{|c|}{ Blood ureum (mg/dL) } & \multicolumn{3}{|c|}{ Blood creatinine (mg/dL) } \\
\hline & \multicolumn{2}{|c|}{ Average level $^{\mathrm{a}}$} & \multirow[t]{2}{*}{ Decrease } & \multicolumn{2}{|c|}{ Average level $^{\text {a }}$} & \multirow[t]{2}{*}{ Decrease } \\
\hline & Day 4 & Day 20 & & Day 4 & Day 20 & \\
\hline Group 1: Control negative & $89.58 \pm 7.84$ & $75.80 \pm 3.95$ & 13.77 & $2.97 \pm 0.40$ & $2.81 \pm 0.33$ & 0.16 \\
\hline Group 2: Control positive & $73.30 \pm 2.75$ & $42.98 \pm 1.34$ & 30.32 & $2.40 \pm 0.09$ & $2.06 \pm 0.14$ & 0.34 \\
\hline Group 3: Extract $100 \mathrm{mg} / \mathrm{kg} \mathrm{BW}$ & $82.64 \pm 7.67$ & $42.38 \pm 3.98$ & 40.26 & $2.73 \pm 0.27$ & $2,11 \pm 0.27$ & 0.63 \\
\hline Group 4: Extract $200 \mathrm{mg} / \mathrm{kg} \mathrm{BW}$ & $76.95 \pm 3.22$ & $40.76 \pm 0.94$ & 36.18 & $2.58 \pm 0.11$ & $1.98 \pm 0.23$ & 0.60 \\
\hline Group 5: Extract $400 \mathrm{mg} / \mathrm{kg} \mathrm{BW}$ & $77.63 \pm 9.46$ & $44.31 \pm 0.63$ & 33.32 & $2.55 \pm 0.37$ & $2.20 \pm 0.19$ & 0.35 \\
\hline
\end{tabular}

${ }^{\mathrm{a} M e a n} \pm \mathrm{SD}, \mathrm{n}=3$

\section{DISCUSSION}

Total anthocyanin in the extract was influenced by the solvent. Polarity compound anthocyanin from red cabbage is lower compared with distilled water. A solvent with the relatively same polarity is suitable for the extraction of anthocyanin. Anthocyanin is classified as semipolar compound (dielectric constant 30-40), while the water is very polar (dielectric constant 80). So that, it complies with ethanol which has a dielectric constant of only 24.30 . 

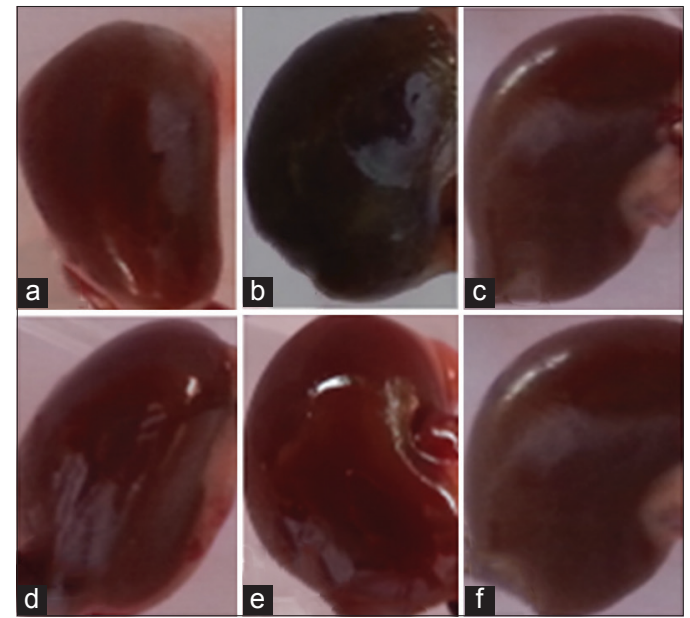

Fig. 2: Macroscopic of rat kidneys, (a) normal or without treatment; (b) negative control; (c) positive controls with Vitamin E $400 \mathrm{mg} / \mathrm{kg}$ BW; (d) extract treatment $100 \mathrm{mg} / \mathrm{kg} \mathrm{BW;} \mathrm{(e)} \mathrm{extract}$ treatment $200 \mathrm{mg} / \mathrm{kg} \mathrm{BW}$; (f) extract treatment $400 \mathrm{mg} / \mathrm{kg} \mathrm{BW}$

According to the previous study, rats were induced by gentamicin and captopril for 3 days to increase the levels of creatinine and ureum to make the rats to be on renal failure. Induction of gentamicin can increase free radicals and nitrosative stress that can damage the kidney $[27,29,30]$. In addition, gentamicin toxicity in the proximal tubules decreases the ability of the tubules to excrete waste products in the blood. Captopril reduces perfusion pressure of the kidney. Captopril inhibits the synthesis of A II intrarenal that required to arterioles efferent renal constriction for maintaining glomerular filtration in the renal artery stenosis. The combination of both drugs resulted in a severe state of the kidney.

Based on one-way ANOVA, increase in creatinine and ureum showed no significant differences for each treatment group, statistically. These results assumed that the induction gives the same effect on various groups. The rat kidney function has been damaged based on paired t-test data, which showed significant difference in increased levels of creatinine and blood ureum compared to day 0 and 4 . It can be concluded that after 4 days of induction with gentamicin and captopril, rats have an azotemia condition. This condition is a decrease in the glomerular filtration rate as indicated by increase of creatinine and ureum levels.

Creatinine and ureum levels decreased significant, statistically. It might conclude that the treatments given (distilled water, Vitamin E, and extract) have different effects on different groups. Based on statistical paired t-test, data indicated a significant difference in decreased levels of creatinine and blood ureum. It showed that there was a repairment on the kidney function on rats. It indicated the effect of anthocyanin pigments of red cabbage extract to repair the kidney function on rats.

The effect of repairment on renal function was due to the active compound content of anthocyanins in red cabbage. Anthocyanin has antioxidant activity, potentially in pressing the occurrence of free radicals from gentamicin that damage kidney cells. Anthocyanin, as an antioxidant, can prevent supercoiled DNA strand cuts caused by reactive oxidative species $[29,31,32]$.

Statistical test results showed that all doses of anthocyanin pigments of red cabbage extract can accelerate the repairment of kidney function. However, dose of $100 \mathrm{mg} / \mathrm{kg} \mathrm{BW}$ and dose of $200 \mathrm{mg} / \mathrm{kg} \mathrm{BW}$ showed significant differences with the negative control in decreased creatinine and ureum levels. It might be said that this dose is effective in accelerating repairment of the kidney function. These results indicated that increased doses were not always linear with the increased on the expected therapeutic effect.
Consumption of anthocyanin allowed per day according to the acceptable daily intake is $0-0.2 \mathrm{mg} / \mathrm{kg}$; excessive consumption can cause toxicity. Toxicity is caused by the increase of antioxidant concentration. Increase of antioxidant concentration affects the rate of the oxidation rate. At high concentrations, the antioxidant activity of phenolic groups often disappears and even becomes prooxidant. Based on that information, the higher dose of anthocyanin can be excessive in the body so that it affects the ability to repair the kidney function.

The previous research used the Wistar strain in male rats weighing 150-200 g; it showed that the weight of a normal kidney is $1.1 \mathrm{~g}$ on the right section and $0.96 \mathrm{~g}$ on the left section with a red-brown color [33]. In early stage of kidney failure, the size of the kidney usually was normal, whereas in chronic renal failure it shows that the kidney size becomes smaller. This study showed that all the group of treatment has a lower kidney weight than a normal kidney. It was likely due to the differences in biological factors of rat, food, habitat, and exposure of inducers given.

\section{CONCLUSIONS}

Extract anthocyanin pigments of red cabbage were shown to repair the kidney function of rats induced with gentamycin-captopril. The extract of anthocyanin could accelerate the repairment of renal functions, in a dose of $100 \mathrm{mg} / \mathrm{kg}$ BW. Further studies should be done using the parameters of superoxide dismutase and malondialdehyde. Research on kidney tissue was performed microscopically to see any changes in the structure of important cells of the kidney due to oxidative stress.

\section{ACKNOWLEDGMENTS}

The authors would like to thank Program Studi Farmasi, Fakultas Matematika dan Ilmu Pengetahuan Alam, Universitas Sriwijaya, for supporting this research.

\section{CONFLICT OF INTEREST STATEMENT}

There is no conflict of interest.

\section{REFERENCES}

1. Wiczkowski W, Szawara-Nowak D, Topolska J. Red cabbage anthocyanins: Profile, isolation, identification, and antioxidant activity. Food Res Int 2013;51:303-9.

2. Wiczkowski W, Szawara-Nowak D, Romaszko J. The impact of red cabbage fermentation on bioavailability of anthocyanins and antioxidant capacity of human plasma. Food Chem 2016;190:730-40.

3. Gomathi P, Prameela R, Sanjeevakumar A. Antioxidant and free radical scavenging activity of anthocyanins from two forms of Brassica oleracea. Int J Pharm Chem Sci 2013;2:1328-32.

4. Adikay S, Sravanthi U. Alleviation of cisplatin induced nephrotoxicity in albino rats by roots of Catunaregam uliginosa. Asian J Pharm Clin Res 2016;9:147-51.

5. Saptarini NM, Wardati Y, Candra EJ. Nephroprotective activities of Artocarpus communis extract against gentamycin induced toxicity in rats. J Med Planta 2013;1:9-14

6. Li J, Kang MK, Kim JK, Kim JL, Kang SW, Lim SS, et al. Purple corn anthocyanins retard diabetes-associated glomerulosclerosis in mesangial cells and db/db mice. Eur J Nutr 2012;51:961-73.

7. Kang MK, Li J, Kim JL, Gong JH, Kwak SN, Park JH, et al. Purple corn anthocyanins inhibit diabetes-associated glomerular monocyte activation and macrophage infiltration. Am J Physiol Renal Physiol 2012;303:F1060-9

8. Kang MK, Lim SS, Lee JY, Yeo KM, Kang YH. Anthocyanin-rich purple corn extract inhibit diabetes-associated glomerular angiogenesis. PLoS One 2013;8:e79823.

9. Li J, Lim SS, Lee JY, Kim JK, Kang SW, Kim JL, et al. Purple corn anthocyanins dampened high-glucose-induced mesangial fibrosis and inflammation: Possible renoprotective role in diabetic nephropathy. J Nutr Biochem 2012;23:320-31.

10. Kataya HA, Hamza AA. Red cabbage (Brassica oleracea) ameliorates diabetic nephropathy in rats. Evid Based Complement Alternat Med 2008;5:281-7.

11. Shafi S, Tabassum N, Ahmad F. Diabetic nephropathy and herbal 
medicines. Int J Phytopharm 2012;3:10-7.

12. Sukandar EY, Qowiyyah A, Minah N. Influence of ethanol extract of binahong (Anredera cordifolia (ten.) steenis) leaves on renal failure rat model. J Med Planta 2013;1:61-8.

13. Sukandar E, Fidrianny I, Adiwibowo L. Efficacy of ethanol extract of Anredera cordifolia (Ten) steenis leaves on improving kidney failure in rats. Int J Pharmacol 2011;7:850-5.

14. Feyissa T, Asres K, Engidawork E. Renoprotective effects of the crude extract and solvent fractions of the leaves of euclea divinorum hierns against gentamicin-induced nephrotoxicity in rats. J Ethnopharmacol 2013;145:758-66.

15. Portella VG, Cosenza GP, Diniz LR, Pacheco LF, Cassali GD, Caliari MV, et al. Nephroprotective effect of echinodorus macrophyllus micheli on gentamicin-induced nephrotoxicity in rats. Nephron Extra 2012;2:177-83.

16. Cai Z, Qu Z, Lan Y, Zhao S, Ma X, Wan Q, et al. Conventional, ultrasound-assisted, and accelerated-solvent extractions of anthocyanins from purple sweet potatoes. Food Chem 2016;197:266-72.

17. Chaiyasut C, Sivamaruthi BS, Pengkumsri N, Sirilun S, Peerajan S, Chaiyasut K, et al. Anthocyanin profile and its antioxidant activity of widely used fruits, vegetables, and flowers in Thailand. Asian J Pharm Clin Res 2016;9:218-24.

18. Jebitta R, Allwin SJ. Antioxidant activity, total phenol, flavonoid, and anthocyanin contents of jamun (Syzygium cumini) pulp powder. Asian J Pharm Clin Res 2016;9:361-3

19. Ramaswamy V, Varghese N, Simon A. An investigation on cytotoxic and antioxidant properties of Clitoria ternatea L. Int J Drug Discov 2011:3:74-7.

20. Anisuzzman M, Zilani MN, Khushi SS, Asaduzzman M, Hossain MG. Antioxidant, antibacterial potential and HPLC analysis of Dioscorea alata Bulb. Indones J Pharm 2016;27:9-14.

21. Kusmardiyani S, Novita G, Fidrianny I. Antioxidant activities from various extracts of different parts of kelakai (Stenochlaena palustris) grown in central kalimantan-Indonesia. Asian J Pharm Clin Res 2016;9:215-9

22. Lee J, Durst RW, Wrolstad RE. Determination of total monomeric anthocyanin pigment content of fruit juices, beverages, natural colorants, and wines by the $\mathrm{pH}$ differential method: Collaborative study. J AOAC Int 2005;88:1269-78.

23. Wang W, Jung J, Tomasino E, Zhao Y. Optimization of solvent and ultrasound-assisted extraction for different anthocyanin rich fruit and their effects on anthocyanin compositions. LWT Food Sci Technol 2016;72:229-38.

24. Patil N, Datar A. Extraction, stability and separation of anthocyanins of Ixora coccinea Linn. Int J Pharm Pharm Sci 2015;7:198-202.

25. Chinnala KM, Achanta P, Vangala VL, Elsani MM. Evaluation for nephroprotective activity of ethanolic extract of Allium cepa Linn in gentamicin-induced nephrotoxicity in rats. Asian J Pharm Clin Res 2017; 10:356-9.

26. Geetha K, Ramarao N, Sindhu B, Rao VU. Nephroprotective, nephrocurative activity of Mimosa pudica root against gentamicin induced nephrotoxicity. Int J Pharm Pharm Sci 2015;7:173-7.

27. Yokozawa T, Kim HY, Nonaka G, Kosuna K. Buckwheat extract inhibits progression of renal failure. J Agric Food Chem 2002;50:3341- 5

28. Ali M, Mruthunjaya $K$, Nandini $C$, Nabeel $K$, Manjula $S$. Chemoprotective effect of noni (Morinda citrifolia L.) fruit juice against cisplatin-induced nephrotoxicity. Int J Pharm Pharm Sci 2016;8:105- 10

29. Virani S, Bhatt S, Saini M, Saxena K. Aloe vera attenuates gentamicininduced nephrotoxicity in wistar albino rats: Histopathological and biochemical changes. Asian J Pharm Clin Res 2016;9:113-7.

30. Pedraza-Chaverrí J, Barrera D, Maldonado PD, Chirino YI, MacíasRuvalcaba NA, Medina-Campos ON, et al. S-allylmercaptocysteine scavenges hydroxyl radical and singlet oxygen in vitro and attenuates gentamicin-induced oxidative and nitrosative stress and renal damage in vivo. BMC Clin Pharmacol 2004;4:5.

31. Hu C, Zawistowski J, Ling W, Kitts DD. Black rice (Oryza sativa L. Indica) pigmented fraction suppresses both reactive oxygen species and nitric oxide in chemical and biological model systems. J Agric Food Chem 2003;51:5271-7.

32. Phukan P, Bawari M, Sengupta M. Promising neuroprotective plants from north-east India. Int J Pharm Pharm Sci 2015;7:28-39.

33. Al-Samawy ER. Morphological and histological study of the kidneys on the albino rats. Al-Anbar J Vet Sci 2012;5:115-9. 